\title{
Uncanny Robots and Affective Labour in the Oikonomia
}

\author{
ANGELA MitRopoulos \\ QUEEN MARY, UNIVERSITY OF LONDON
}

\begin{abstract}
Her pace is strangely regular, every movement seems to depend on some wound-up clockwork. Her playing and her singing keep the same unpleasantly correct and spiritless time as a musical box ... We find your Olympia quite uncanny ... She seems to act like a living being, and yet has some strange peculiarity of her own.
\end{abstract}

E.T.A. Hoffmann, 'The Sandman' (1816). ${ }^{1}$

... the boundary between science fiction and social reality is an optical illusion.

Donna Haraway, 'A Cyborg Manifesto: Science, Technology and SocialistFeminism in the Late Twentieth Century' (1985). ${ }^{2}$

There was much that was uncanny about Australia's 2010 federal election; that is to say, numbingly familiar and yet deeply strange. The rightward convergence between the major parties, monotonously observed during the election campaign, metamorphosed into a hung parliament. It is a parliament that-or so it would 
seem-runs counter to the more visible conservative trajectory we had become accustomed to over the previous decade. Labor and the Liberal-National Coalition, increasingly narrowcasting their pitch to a few thousand swinging voters in marginal electorates, failed to gain a majority of seats, and appeared to be leaking to their left. Three independents (two of whom had previously been members of the Nationals) turned out to be less conservative than both the Labor Government and the Liberal-National Opposition on the prominent issues of unauthorised boat arrivals, climate change and marriage laws. How this plays out in government remains a question, even if in this respect that question often becomes reduced to a mathematical one. It would be a mistake to think this signals a definitive move in Australian politics. But it would be just as erroneous to not consider the implications of this uncanny unfolding, evident in far more than a finely balanced parliament. That the unpredictable reappeared in politics, in the immediate wake of what many regarded as the most boring election in recent memory, should give pause. This is not meant to suggest a renewed optimism or faith in government, structurally bound as it is to three-year cycles of appointment and disappointment, or worse. It should, on the contrary, indicate a crucial distance between the policies of governments and politics in its broader, lived and untrammelled senses. If not quite cause for celebration, this gap nevertheless hints not-as is so easy to imagine-at the ongoing strength of various policies, but to their uncertain and incomplete reach. It is this distance, pointing as it does to a discrepancy between complex realities and political conventions, that elicits a sense of the uncanny.

But there is something more specific than brittle norms in evidence, threading together the presumptions of migration and welfare policies, underwriting economics and shaping approaches to ecology, very much taken for granted and yet, for all that, boosted with hyperbole, subsidy and sentiment. Put simply, the argument here is that the familial household is both assumed and perturbed, presented as the model and situated as the object of government in each of these areas, a financialised version of a familiar orthodoxy at once economic, intimate, national, sexual and aesthetic. The appearance of the uncanny, in this reading, suggests the appearance of a deeper conflict around these issues, even as it is rarely recognised as such in the canonical terms of political analysis. In order to make sense of this, the analytical and disciplinary boundaries between the cultural and the 
political, or the aesthetic and the economic, have to be traversed-just as, it might be noted, the figure of the uncanny points to their indistinction and, not least, because of the post-Fordist centrality of the affective, the cultural and the household to financial processes, markets, work and political economy more generally. ${ }^{3}$

More famously than 'The Sandman' to which the idea of the uncanny has been traced, Freud's 1925 essay 'The Uncanny' ('Das Unheimliche') on Hoffmann's short story defines heimliche as 'belonging to the house, not strange, familiar, tame, intimate, friendly, etc.' ${ }^{4}$ One does not have to follow Freud's rather ahistorical take on the oedipal, ${ }^{5}$ however, to discern the crucial insight that the uncanny discloses about the familial, the intimate and the household. The uncanny gathers around that which seems most mundane, yet imparts a feeling that what is most familiar is a matter of automation. It is a convention become so accustomed and passionless as to appear mechanical, bereft of emotional intensities and connection. It is the almost indefinable feeling that fact is manufactured. The field of the uncanny is at once odd and everyday. As Stanley Cavell put it, the uncanny is 'the surrealism of the habitual'.6 In its literary and cinematic genres, as with 'The Sandman', the uncanny has almost invariably assumed the character of a female robot. From Hoffmann's Olympia, to the portrayal of the robot-Maria in the 1927 German Expressionist film Metropolis, to that of Six (and others) in the recent television series Battlestar Galactica, the figure of the female robot (and cyborg) is positioned at the uneasy articulation between what is deemed to be natural and that which is construed as cultural. Yet, in its suggestion of an authenticity, however unsettled, such figures in their conventional form tend to reassert the sense that there is something natural before or beyond the processes of cultural artefaction. This is unsurprising, since women are often burdened with conveying the supposed essence of what is natural, the cultural markers of an ostensibly foundational biology and the naturalised reproduction of 'life' situated as both fundament of and refuge against the putative degradations of technology, transaction and artifice. ${ }^{7}$ And this, in brief, is the reason Donna Haraway, in writing her 'ironic political myth' of the cyborg, opted not for a naturalist reconstitution of the demarcation between machine and human but argued instead for taking pleasure in the confusion, insisting that the 'stakes in this border war have been the territories of production, reproduction and imagination.'8 If Haraway's intervention was oriented toward a critique of what might be 
construed as the properly natural space and demeanour of the feminine, alert to the industrialisation that had shaped both home and factory along with the very difference between them, ${ }^{9}$ and therefore wary of the implications of sentimentalising the former, the present suggests no less attention to what the restoration of neatly gendered demarcations seek to call forth. In what follows, then, the argument is not that the art of government might be juxtaposed to some genuine realm of the everyday, or of life assumed to reside outside the volatile meshings of culture, technology, economics and politics, but that the uncanny signals the appearance of a new 'border war' around the demarcation of what is properly political from that which is posited as natural and, consequently, regarded as an improper subject of cultural and political conflict. The uncanny would not be so if it did not, as Alison Landsberg has noted, deploy the premise of an authenticity disturbed. ${ }^{10}$ Yet, in speaking directly (as Haraway contended) to the question of the vexed boundary between nature and culture, and in the sometimes ambivalent admixture of desire and anxiety that the uncanny elicits, it nevertheless simultaneously points to attempts to reimpose that demarcation in a new form and indicates that the boundary has not quite held as firmly as might be supposed.

Put more precisely, the figure of woman-robot has assumed a literary and psychoanalytic density as emblematic of complex shifts in sexuality, domesticity, gender, technology and work across the previous two centuries. Writing in the early nineteenth century, Hoffmann's depiction of Olympia as the enticingly fatal robot not only took shape against the backdrop of an expanding industrialisation, in what Minsoo Kang has called the automaton craze that swept across Europe, and at the close of the Luddite campaigns against the mechanisation of the textile industry in England.11 It took place at the very moment when the number of women in regular paid work-having increased most notably through and alongside the industrialisation of textile production-began to decline because of campaigns to remove women and children from the factory through so-called protective legislation and the emergence of the family wage, to be replaced by systems of day labour for women and an increasing dependance on male earnings defined as a 'breadwinner' wage.12 Set in the midst of these complex shifts between public and private labour, ${ }^{13}$ the contested and gendered lines between paid, unpaid and precarious work, and the early association of mechanisation with the increasing 
economic independence of women, it might come as no surprise that Hoffmann's story of the uncanny restores the properly familial by narrative's end with a scene, as he puts it, of 'quiet domestic happiness'. Following the work of Ivy Pinchbeck on this period, Sara Horrell and Jane Humphries note that these changes were 'neither welcome nor understood by the men and women who lived through' them. ${ }^{14}$ Even so, Hoffmann's short story dramatised, in literary form, burgeoning fears and desires on the eve of what would become an almost global transition to the family wage over the next two centuries. Since the Harvester Judgment in Australia in 1907 , the basic wage has been more or less defined as a family wage paid to men as breadwinners. ${ }^{15}$ In Metropolis, a critique of the expansion of the Fordist assemblyline and the application of Taylorism of the early twentieth century is resolved through a return to the authentically feminine-the death of robot-Maria and the return of real-Maria-as the basis of a new, harmonious social contract between labour and capital. Indicative of the rise of German fascism, not least in its implicit anti-Semitism, in its final sequence the film nevertheless serves as a striking anticipation of the Keynesian settlement in the wake of World War II.

It might then be said that nascent but seismic shifts surface in stylised cultural forms well before they rise to prominence as matters of sustained sociocultural analysis or research. At present, the becoming everyday and intimately personal of programming, technology and automation ${ }^{16}$-and the associated expression of anxieties and desires that turn around the disrupted binaries of gender and sexuality, as much as they do those of organism and machine, or politics/aesthetics, or nature/culture-is similarly apparent in the slips between literature and electoral commentary. And, during the most recent federal election in Australia, journalists did, fleetingly but remarkably, become preoccupied with the literary device of the female robot. While Julia Gillard's mechanical performance in the opening weeks of the election campaign was widely construed as an index of just how dull politics had become, its importance may well lie not in demonstrating the dominance of 'machine party politics' but, more interestingly, in registering a significant moment of cognitive dissonance-even, as in this instance, in the Prime Minister herself as she articulated the Labor Party's policies on border control, paid homage to working families and the dignity of labour, was compelled to prove, time and again, that she really did care about children. As the election campaign began, 
Jennifer Hewett, writing in the Australian, complained that 'The PM's firm and feisty image is being replaced by that of a hesitant, over-rehearsed political robot.'17 Paul Sheehan wrote of her as a 'metallic creature of the machine'-from whom, according to him, the public had recoiled-in an article titled 'In one month, a good woman has become Labor's latest robot'.18 The next day, Emma Chalmers noted, with manifest relief, the appearance of 'a less robotic Ms Gillard'.19 These references to a robotic Gillard had something to do with Tony Abbot's repeated remarks about the 'machine men' in the ALP, who had overthrown Kevin Rudd and installed Gillard as leader of the Labor Party. They also echoed a longstanding attempt to depict her as bereft of proper (womanly) affect and attachments because she is neither married nor a mother. In 2006 and reiterated in 2007, then-Liberal Senator Bill Heffernan accused Gillard of being 'deliberately barren', and therefore unfit to hold office. ${ }^{20}$ Heffernan was forced to apologise, though the implication that Gillard's choices impair her representative standing remained in play. Mark Kenny, in an op-ed piece for the Adelaide Advertiser written just after Gillard's ascendancy and almost a month before the election, accused parts of the media, the Liberal Party and someone from inside the ALP of being complicit in a campaign to deliver an 'encrypted message ... that Julia Gillard is a childless, career-obsessed feminist, unmarried by choice, and not interested in the normal things such as children, families and the elderly'. He went on to note that this amounted to 'a pitch-perfect reinforcement of a preexisting conservative view about what women should think-assuming they are normal-and how they should carry themselves in politics'. ${ }^{21}$ But the remarks by these journalists, while they certainly did this and more, giving a definitive nod to the derogatory and the normative, turned more explicitly on Gillard's obvious aloofness. As Gillard's polling declined in the wake of what was often a vicious campaign around the impending introduction of a carbon tax in late 2011, another journalist remarked that 'public opinion' viewed her as 'somehow soulless', while a second echoed this in concluding that this was 'a problem which can only be fixed by acting and speaking naturally'.22 In short, she seemed affectively detached from the policies she articulated.

This, I come to suggest in concluding this essay, undoubtedly takes place within the register of the uncanny, illustrating the affective fault-lines of the present moment. Hoffmann's ultimate complaint about Olympia is that she does not express 
a naturally feminine affective range in voice and movement. Yet my concern here is neither to make an argument about or for 'the real Julia Gillard' (Labor's eventual riposte to the charge of mechanisation); 23 nor, quite, to argue that her politics might be less conservative than they appeared, and might therefore hold promise. Her depiction and presentation raises, I would suggest, a larger question about the specific and contested confluence of economics, politics and intimacy that might be called oikopolitical (the politics of the household). Economics, it might be noted, derives from oikonomia - that is, the law of the household; as does ecology. While the history of this concept can be traced to Aristotle's moralising proposition of a properly productive household, ${ }^{24}$ the present conjuncture is saturated by a politics in which nation, sexuality, gender, race and environment are all thought in oikopolitical terms, and, more concisely, in terms that serve as bedrock for neoliberalism but also curiously remain intact as restrictive assumptions for its ostensible critics. The oikonomic adherence of government policy runs against the assumption, axiomatic for some on the Left, that capitalism (or its neoliberal variant) undermines the ostensibly natural or pre-political bonds of family, race and nation. As argued elsewhere, this assumption does not correspond with the empirical flow of history; indeed, this law of the household serves as restorative fundament in times of crisis and scalable vector in moments of speculative expansion. 25

The concept of an oikopolitics is borrowed from Hannah Arendt. Writing in The Human Condition, and having in mind not only the experience of fascism but also post-war Keynesianism, for her this oikopolitics was discernible in the organisation of politics 'in the image of a family whose everyday affairs have to be taken care of by a gigantic nationwide administration of housekeeping'.26 Following Arendt, Elizabeth Povinelli has argued that such a politics hinges on the conflation of intimacy and genealogy that expanded with colonisation and which, in turn, organises and legitimates the distribution of goods, services, welfare and property. ${ }^{27}$ For my part, I would add that the genealogical and its oikonomic correlates are the lynchpins of private property, its transmission and rights, and so the critical element in the perseverance of capitalism across time and space. ${ }^{28}$ This analytical paradigm goes beyond the theoretical impasse of thinking historical processes as if they are a consequence of already-given, discrete identities, whether those of class, race, 
gender or sexuality. At the same time, it delves into the racialising, sexual, national and gendered conditions that constitute and reconfigure biopolitical re-/production. Yet while an oikopolitics can be made out in its varied articulations across more than two centuries, evident in the swings that saw women enter and exit particular occupations; in the affiliated architectures and domestic semantics of home, workplace, and nation; in marriage laws that banned 'miscegenation' or sought to 'breed out the colour'; in the emergence of migration policies based on legitimated genealogical lines-the current tension consists more specifically in the indistinction between intimacy and economy that plays out, among other things, as the expectation that women who work (whether in private or public, paid or not) deliver a labour that has affective purchase, circulating as an extension of (rather than refusal of or indifference toward) care-giving domestic labour that has to appear as if it is not work at all, but freely and naturally given. ${ }^{29}$

It comes down, in other words, to the extension of surplus labour-though not perhaps in exactly the ways in which Karl Marx acknowledged it. ${ }^{30}$ This surplus and its channelling-its distribution along and through oikonomic lines-is the key to understanding the coincidence of austerity at a time of abundance. ${ }^{31}$ The present oikonomic configuration turns on the privatisation of welfare, health care and education over the last two decades that, along with the relative stagnation of wages and restructuring of the workplace over a similar period, constituted the household as the basis (rather unsteady as it happens) of financialisation. In 2005, the International Monetary Fund noted that the finance sector had displaced its risks onto households, remarking (hoping) that the household would act as its 'shock absorber of last resort'.32 The so-called turn to neoliberalism amounted to the household becoming the tense locus of personalised risk management, indebtedness, welfare provision and the expansion of unpaid labour. Furthermore, by far the greater proportion of work in Australia is in healthcare, education, hospitality, public administration, financial services, recreation, and retailing. That is to say, while the gap between men's and women's incomes has grown in previous years because of the mining boom, most employment is in areas that involve an element of personal (that is, affective) interaction, and which (particularly in retail and hospitality) are increasingly precarious. With the decline of welfare, the privatisation of education, the introduction of compulsory private superannuation, 
and the shift to commercialised health care, housing increasingly assumed the additional roles of collateral, investment, insurance and safety net. More broadly, the household was located at the centre of a financial complex that sought to diffuse risk, organise its management and enforce the intimate expectations of human capital formation. As Michael Rafferty and Serena Yu argued in their report to the Australian Council of Trade Unions, the most recent financial crisis 'revealed how much more all workers and households are integrated into financial processes and calculations in their everyday life, a process coming to be known as "financialization"'.33

But however pronounced this oikopolitical assemblage is, it goes against the trend of lived realities. Put another way, the demand for genuinely normative affective performance would not be quite so dogmatic were the oikonomic arrangements that underwrite the economy assured. The discrepancy is allimportant. On the one hand, there is the exaggerated repertoire of current policy: border control, the rise of the figure of the Working Family, the Intervention (that is, the Northern Territory Emergency Response, and further changes to welfare), the financial crisis, and climate change. These are all approached as instances of household management, replete with claims about filiation, merit and genealogical right. On the other hand, there are the dramatic shifts in how people live, most easily situated from the 1970s on, that indicate the object of the these policies but also the scope of their inoperability. Still, mainstream economic (and ecological) perspectives demand adherence to their etymological foundation in the oikos at the very moment of the household's most striking incertitude. Detailed attention given to Gillard's living arrangements betray a rather traditional view of women and politics among some. But the way in which her decisions have been regarded as suspect points to a wider context in which gender, nation, sexuality and race are routinely combined to prove the existence of a problem regarded as self-evident. A statistical catalogue of declining rates of marriage, shorter marriages, rising divorce, dropping childbirths and changes to household composition is presented as the signal of a failure to reproduce the nation, and here re-/production is understood in its simultaneously economic, racial and sexual senses. The presumption that this marks a failure, and of what, is hardly ever explored, let alone challenged. In 2004, then-Treasurer Peter Costello suggested, as part of a government that had insisted 
on violently stopping unauthorised migration, that women should have three babies to ostensibly stem the decline in Australia's population. In 2006, a news report carried Costello's boast in these terms: 'Australian women appear to have succumbed to Treasurer Peter Costello's charms, taking up his challenge to have more babies for the good of the nation'. ${ }^{4}$ That is to say, after years of changes to tax and employment policies that, as Deborah Brennan has shown, expressed 'hostility towards mothers' workforce participation'.35 In any event, statistical projections continue to forecast either static or declining birthrates, ${ }^{36}$ irrespective of any recent panic about overpopulation that amounts to a racialising displacement of problems to do with transport, urban planning, incomes, housing and energy. As Jacques André put it in another context: 'the racial question is from start to finish a sexual question'.37 In other words, the implicitly racialised and heteronormative assumptions of demography-which draw a cultural and legal line between population and citizenship founded on the characterisation of nation as familial home-and the national configuration of the environment have been accompanied by climate change policies rarely criticised for placing the greatest burdens on households, not least by increasing the amount of (still largely female and unpaid) domestic labour that goes into schemes with little discernible environmental benefit. ${ }^{38}$ Yet if ' $[\mathrm{g}] \mathrm{ood}$ environmental stewardship' has been recently defined by mainstream ecologists as akin to 'good household management' (as did Andrew Simms, the author of Ecological Debt, echoing Margaret Thatcher's homilies about household economics ${ }^{39}$ such analogies have become that much tighter in migration and welfare. In effect, what these moves accomplish is the depoliticisation of cultural and economic practices, relocating the pertinent questions to the naturalised terms of an oikonomics: family, race, nation, heterosexuality, and the reproduction of each in their inseparable arrangement.

It is perhaps not necessary, here, to rehearse in detail the ways nations and the distribution of right are thought along genealogical lines. ${ }^{40}$ What may need to be stressed is that the measures of the Australian Northern Territory Interventionundermining of communal landholdings, banning pornography and alcohol, authoritarian and punitive changes to welfare-are indeed disciplinary as many have argued, but they are not simply biopolitical, as Dinesh Wadiwel and Deirdre Tedmanson suggest; ${ }^{41}$ rather, their specificity is oikonomic. As Nicole Watson 
pointed out, the Intervention was driven not only by the 'criminalisation of poverty,' but also by an 'obsession with home ownership.' 42 The Intervention has at its core the imposition of an oikopolitics at its most normative: the enforcement of rules regarding proper household management, the determination of legitimate lines of obligation and interdependency, decrees of the at once properly familial and decently productive, for the most part through the much-touted virtue of private home ownership. As Indigenous people became in this instance the apparently effortless laboratory for more recent changes to welfare, ${ }^{43}$ the path from welfare to workfare to normfare can be traced, locally, to the Keating Government's adoption of mutual obligation policies and, globally, to the rise of the Working Family in Labor and Democrat approaches in the United Kingdom, Australia and the United States. Emphasising the ways in which the family came to be overtly posited as a re/productive unit, and by implication accentuating the concept of the deserving poor as a genealogical matter, the Working Family is as much about economics as it is about the oikonomic nexus of sex, race, class, citizenship and gender, the making intimate of the injunction to be properly productive and virtuously reproductive. In Australia, the normatively gendered demand to deliver up gratuitous labour referred to earlier takes place within the steady rise of what, in recent Australian history, Holly Randell-Moon has highlighted as the intersection of Christian nationalism with neoliberalism, and what Barbara Baird has analysed as the increasing merging of a politics of familial and national reproduction as it pivots on the figure of childhood innocence. ${ }^{44}$ Yet nowhere, perhaps, have these conjunctures of racial, sexual and economic policies been more apparent than in Bill Clinton's Personal Responsibility, Work Opportunity and Medicaid Restructuring Act of 1996. Those laws declared that 'marriage is the foundation of a successful society', outlining a series of mostly punitive measures to give effect to this, while also barring (legal) migrants from welfare. This, of course was the same year of the Defense of Marriage Act; the same year Clinton passed laws that resulted in the militarisation of the US-Mexican border and a predictable escalation of deaths. ${ }^{45}$ As Rafferty has indicated of recent proposed changes to welfare policy in Australia, announced by Gillard in a speech entitled 'The Dignity of Work,' these 'brought an international movement to restructure welfare to full bloom in Australia'. According to Rafferty, both sides of politics in Australia 'have made it clear that they believe 
that the moral failure of having a baby out of wedlock, or in your teens, can only be redeemed by paid work'.46 In any event, that both the Gillard Labor Government and the Greens (led by an openly gay man) have felt obliged to amend the detention of unauthorised migrants only insofar as this impacts upon families with children may well ease the distress caused to some of those who are extrajudicially detained. But why are those who are married and with children seen as more deserving of freedom by parties whose leaders are anything but? The discrepancies should be more than apparent. As Misha Schubert suggested recently, Gillard's stated position against gay marriage doesn't 'ring true'.47 That is to say, these are politicians, such as Clinton and Gillard, who pronounce support for policies whose assumptions they themselves do not, in their actual daily practices and choices, seem to share. This is not a simple instance of hypocrisy. Having assumed the task of representing the nation, the rest unfolds as if inexorably.

Nations are habitually considered as the larger cognate of the family. Drawing the boundary of politics, but also defining what is deemed to be natural as that which lies beyond political dispute, the analogy is nevertheless mutually constitutive of a depoliticisation. While construing the nation in familial terms seeks to naturalise its boundaries, buttressing it with assumptions of biological origin, the history of marriage laws illustrates that this supposedly natural basis is similarly an artefact, a consequence of laws and conventions. It is marriage laws which have legitimated offspring and created illegitimacy, determined the transmission of wealth and excluded others from it, legalised particular forms of interdependency while criminalising others, reduced sexuality to two and defined it as a matter, above all, of property. The legal fiction of property, in turn, is assumed to flow from the rights conferred by genealogical lines of descent (a property of what is proper) rather than convention. The significance of the recent passage of marriage laws in Australia (as in the United States), characterising marriage in strictly heterosexual terms for the first time in history, is not quite at odds with proposed regulations governing civil unions. To the extent that provisions of the latter dictate exclusive, monogamous couplings (as Sydney City Council recently set forth), the question these laws answer is not only that of sexuality or intimacy (though the model remains heteronormative), but what legitimate sexual connection should result in and be: namely, the familial ordering and transfer of property. Changes to tax, 
insurance and similar policies might have recognised same-sex couples, but in effect this means that sharing material resources with anyone other than one other person on these terms is penalised or ruled out. As Priya Kandaswamy put it in a discussion of gay marriage and racism, the state 'recognizes a very particular kind of relationship in its recognition of gay marriage, a relationship that is structured by the idiom of property'.48 Marriage makes property arrangements and their transfer legible, literally reproducing the inequalities of class and race as if they are a result of biological attachment. In this regard, the insecurity that has been amplified by decades of neoliberalism invests marriage with ever greater import, not least in a context where financial calculation becomes an increasingly intimate matter, where familial ties become the very condition of migration, of health care, or education and so on. Neoliberalism does not, then, fragment the putatively natural attachments of family, nation and race. On the contrary, it literally widens and deepens their affective purchase. Still, laws such as those of the Marriage Act would not be deemed necessary if intimacy was not, as it happens, becoming a more complex matter for many, increasingly something other than life-long, monogamous and/or heteronormative arrangements, whether queer or straight. The conventional model of intimacy was, to put it schematically, the accompaniment of a period and type of industrial production. Life-long attachment to a particular occupation and/or employer was, in its early Fordist days, the condition of the relatively higher family wage granted to husbands and fathers.

In any case, recent analyses of work, of its transformation and significant aspects over the last two decades, turn around the key themes of affect and precariousness. Post-Fordism is defined by a meshing of worktime and the time of life, the demand to be constantly available, always preparing for work. ${ }^{49}$ Social networking is also net-working.50 Particularly in the still-feminised occupations of care and service work, in the expanding post-Fordist areas of the economy, with its own particular exertions, fatigue and forms of an oftentimes intimate selfmanagement, it is affects that are put to work. Akseli Virtanen, Paolo Virno and others have theorised affective labour as the valorisation of human sociability as such. ${ }^{51}$ Setting aside an easy distinction between human and machine, Patricia Clough et al argue 'that there is an abstracting of affect to affect-itself, which disregards the bounded-ness of the human body, thus troubling the 
conceptualization of the body as the body-as-organism'.52 Along similar lines, Kathi Weeks has insisted that there is an impasse in presenting 'a true self versus its estranged form, or a reproductive sphere of practice separate from a sphere of properly capitalist production'.53 The divergence between these two accounts is significant, not least because the latter presume a feminist, anti-racist and queer critical history leery of the implicit proposition, in Virno's account and that of others, of nature deformed by cultural and economic processes. That said, as I have been arguing, it is not authentic human sociability that is valorised in affective labour, but the apparently genuine circulation of affect as if it is not work. Affective labour, whether paid or not, has long circulated as part of a compensatory logic, offered as a humanisation of the mechanisation of the labour process, in both Fordism and postFordism. In this respect, it is not simply a question of lamenting the indistinction between life and work as if the former might offer refuge, but of noting the ways in which a politics of the re-enchantment of life proceeds alongside the infinite expansion of worktime. Melinda Cooper, in her discussion of the complex articulations of neoliberalism and anti-abortion politics in the United States, has suggested that fundamentalism emerged here as an attempt to 'reimpose the property form in and over an uncertain future', a form that 'as the right-to-life movement makes clear, is inextricably economic and sexual, productive and reproductive. It is ultimately a claim over the bodies of women'.54 What I would emphasise is that the incertitude of property rights is resolved through recourse to genealogical inscription. 55 Moreover, oikonomia legitimates the distribution of surplus labour. It is, then, not a matter of reinstating a 'work-life balance', inasmuch as that restoration might be tacitly understood as, or in practice entail, the return of (largely) women's time to unpaid domestic work and the reproduction of life. ${ }^{56}$ Nor would it be a matter of denouncing the enslavement that is implied by the indistinction of worktime and that of life, as if unpaid and poorly paid labour has not always been the precondition of the circumscribed 'normal working day'.57 The expansion of precarious work, the increasingly widespread predicament of infinite worktime that has overtaken the demarcations between life and labour need not play out, once again, as the naturalised allocation of surplus labour along oikonomic lines. 
Nevertheless, given the indistinction between worktime and the time of life, the question of how workers might take (what might be redundantly referred to as) industrial action becomes both more difficult to answer and all the more pressing. To be sure, there is a more complex story to be told about both affective labour and precarious work, not least because these are hardly new, even if they are new experiences for some; and even as they emerge as novel motifs in social analysis, likely because over the last two decades these forms of work have come to impact upon the experience of work for white, middle-class men in metropolitan countries. Still, the question of what to do when the strike becomes structurally implausible, when workers are spatially and temporally disaggregated, or when the work contract is both precarious and infinite in its reach, becomes a more pertinent one for all that. My conclusion here is that given the pertinence of (faking) affective attachment, what becomes increasingly troubling is precisely that which Gillard was accused of. In The Managed Heart, Arlie Russell Hochschild, remarking on the strategies some flight attendants use when confronted with speed-ups, wrote: 'Workers who refuse to perform emotional labor are said to "go into robot". They pretend to show some feeling. [Yet in] the conditions of speed-up and slowdown, covering up a lack of genuine feeling is no longer considered necessary. Halfheartedness has gone public.'58 Perhaps, then, the oikos is haunted not by communism - at least as it has come to be understood, as party or state or policybut by disaffection, a detachment from the oikonomic that signals attachments otherwise and, for this reason, barely deciphered by conventional political analyses, but nevertheless distinctly uncanny.

Angela Mitropoulos is affiliated with Queen Mary, University of London. Much of the analysis for this essay draws on earlier texts such as 'Precari-Us?' (Mute), 'Oikopolitics, and Storms' (The Global South), and is developed more fully in Contract and Contagion: Oikonomia, Intimate Self-Management and the Limits to Speculation (forthcoming). 
-NOTES

1 See <visuality.org/genderandtechnoculture/the_sandman.doc>.

2 Donna Haraway, 'A Cyborg Manifesto: Science, Technology and Socialist-Feminism in the Late

Twentieth Century', in David Bell and Barbara M. Kennedy (eds), The Cybercultures Reader, Routledge, London, 2000, p. 291.

3 On financialisation and the household, see Fiona Allon, Renovation Nation: Our Obsession with Home, University of New South Wales Press, Sydney, 2008; Melinda Cooper and Angela Mitropoulos, 'In Praise of Usura', Mute, vol. 2, no. 13, 2009, <www.metamute.org/content/in_praise_of_usura>; Dick Bryan and Michael Rafferty, 'Homemade Financial Crisis', Ephemera, vol. 9, no. 4, 2009,

$<$ www.ephemeraweb.org/journal/9-4/9-4bryanrafferty2.pdf >, and Randy Martin, Financialization of Daily Life, Temple University Press, Philadelphia, 2002. On the heightened pertinence of affective and intimate economies, see Lauren Berlant, The Queen of America Goes to Washington: Essays on Sex and Citizenship, Duke University Press, Durham, NC, 1997, and the edited anthologies by Patricia Clough and Jean O'Malley Halley, The Affective Turn: Theorizing the Social, Duke University Press, Durham, NC, 2007, and t Melissa Gregg and Gregory J. Seigworth, The Affect Theory Reader, Duke University Press, Durham, NC, 2010. The theorisation of money, finance and debt as cultural practices has only recently become a matter of sustained research. Of interest here are texts such as those by Mary Poovey, Genres of the Credit Economy: Mediating Value in Eighteenth- and Nineteenth-Century Britain, University of Chicago Press, Chicago, 2008; Marieke de Goede, Virtue, Fortune, And Faith: A Genealogy Of Finance, University of Minnesota Press, Minneapolis, 2005; and Nicky Marsh, Money, Speculation and Finance in Contemporary British Fiction, Continuum, New York, 2007.

4 Sigmund Freud, The Uncanny, Penguin Books, London, 2003, p. 126. See also Stephen Keane, 'Imaginary Homelands: Notes on Heimat and Heimlich', Angelaki, vol. 2, no. 1, 1997, 81-9.

5 The argument against Freud's ahistoricism, briefly, is that he places what can only be discerned as a condition of familial and middle-class European psychic space that emerged from the eighteenth century under the heading of an ancient Greek narrative, the implication being one of archaic origin; though its premise is the steady demarcation of work and home from the seventeenth century, a distinction that simply did not obtain in antiquity.

6 Stanley Cavell, In Quest of the Ordinary: Lines of Skepticism and Romanticism, Chicago University Press, Chicago, 1988, p. 154.

7 Schematically put, across the eighteenth and nineteenth centuries the spaces of home and factory were demarcated in such a way that the former was posited as a realm of private, familial affection that, in any event, allowed for the humanisation and reproduction of the male domination of the latter. In the Fordist period of much of the twentieth century, this distinction was formalised in the accounting of the family wage (on this, see my 'Oikopolitics, and Storms', The Global South, vol. 3, no. 1, 2009, pp. 6682). The feminist campaigns from the mid-twentieth century on, around equal pay, unpaid domestic 
work, divorce laws, contraception and abortion, highlighted (among other things) the ways in which the Fordist demarcation of production and reproduction was mutually constitutive. Post-Fordism, by contrast, situates the affective, the household and reproduction at the very centre of markets, finance and politics (see note 3).

8 Haraway, 'A Cyborg Manifesto', p. 292.

9 Kerreen M. Reiger, The Disenchantment of the Home: Modernizing the Australian Family 1880-1940, Oxford University Press, Melbourne, 1985.

10 Alison Landsberg, 'Prosthetic Memory: Total Recall and Bladerunner', in Bell and Kennedy (eds), The Cybercultures Reader, p. 195.

11 Minsoo Kang, Sublime Dreams of Living Machines: The Automaton in the European Imagination, Harvard University Press, Cambridge, Mass., 2010, p. 174. On the Luddites, see 'The Declaration of the Framework Knitters' [1812], <www.marxists.org/history/england/combination-laws/ned-ludd1812.htm>.

12 Sara Horrell and Jane Humphries, 'Women's Labour Force Participation and the Transition to the Male-Breadwinner Family, 1790-1865', Economic History Review, vol. 48, no. 1, 1995, pp. 89-117. 13 For much of the eighteenth century in Europe, most textile production was undertaken in the household by women.

14 Horrell and Humphries, p. 89.

15 As Gillian Whitehouse suggested of early Australian wage determination, the protectionist measures of the family wage, along with the White Australia policy and legislation pertaining to Indigenous and Pacific labourers, meant that protection applied largely to white men. 'Justice and Equity: Women and Indigenous Workers', in Stuart Macintyre and Joseph Ezra Isaac (eds), The New Province for Law And Order: 100 Years of Australian Industrial Conciliation and Arbitration, Cambridge University Press, Cambridge, 2004, pp. 207-40.

16 This essay is not, however, an extended discussion of information technologies, though it remains implicit. On this, see Susan Hawthorne and Renate Klein (eds), Cyberfeminism: Connectivity, Critique and Creativity, Spinifex Press, Melbourne, 1999; and Zoë Sofoulis, 'Virtual Corporeality: A Feminist Perspective', Australian Feminist Studies, vol. 15, 1992, pp. 11-24.

17 Australian, 31 July 2010.

18 Sydney Morning Herald, 2 August 2010.

19 Herald Sun, 3 August 2010.

20 Dan Harrison, “'Barren” Gillard blasts Heffernan', Age, 2 May 2007.

21 Adelaide Advertiser, 28 July 2010.

22 Jacqueline Maley, 'When in Public, Gillard is not at Home with the Lingo', Age, 13 September 2011; Martin Flanagan, 'Capturing Our Female Prime Minister', Sydney Morning Herald, 17 September 2011. 23 Phillip Hudson, 'Who is the Real Julia Gillard', Herald Sun, 3 August 2010. 'The Real Julia Gillard', ABC Radio, 2 August 2010, <www.abc.net.au/local/stories/2010/08/02/2971264.htm>. 
24 Aristotle distinguished between practices he described as oikonomic and those he denounced as chrematistic. The first he defined as properly productive, a natural economy; the second as consisting of the unproductive circulation and expansion of money. Significantly, for Aristotle and the ancient Greeks the oikos was not synonymous with the familial household. It is only later, as the Catholic Church elaborated its principles of marriage and sexuality, that the Scholastics posited the familial household as the space of the properly re/productive. For a discussion of this in relation to the collapse of the subprime housing market in the United States, see Cooper and Mitropoulos.

25 Angela Mitropoulos, 'Legal, Tender: The Genealogical Economy of Pride, Debt and Origin', Social Text, vol. 29, no. 3, 2011, pp. 73-91.

26 Hannah Arendt, The Human Condition, Chicago University Press, Chicago, 1998, p. 28. I remain critical of Arendt's argument in the detail, but suffice to note that while Foucault discusses many of the same historical shifts as does Arendt, her striking absence from his analysis underlines the need to move beyond theories of biopolitics to a critical understanding of oiko-politics.

27 Elizabeth A. Povinelli, The Empire of Love: Toward a Theory of Intimacy, Genealogy, and Carnality, Public Planet Books/Duke University Press, Durham, DC, 2006.

28 It might be noted that I do not use genealogy here in the sense usually understood as a Foucauldian methodology. Indeed, I argue elsewhere (in Contract and Contagion) that Foucault's oblique reading of Nietzsche is circumvented by his remarks on parrhesia, and that he returns in his later writings to a neo-Aristotelian romanticisation of the oikos as the premise of his ethics. Here and in other writings, I regard genealogy as a matter of legible re/production and the rights associated with it. For a psychoanalytically inflected discussion of the connections between heterosexuality and futurity, see Lee Edelman, No Future: Queer Theory and the Death Drive, Duke University Press, Durham, 2004. 29 Leopoldina Fortunati has argued that reproductive labour is 'the creation of value' that 'appears otherwise' (The Arcane of Reproduction: Housework, Prostitution, Labor and Capital, Autonomedia, New York, 1995, p. 8). David Staples takes this up in relation to affective labour in 'Women's Work and the Ambivalent Gift of Entropy,' in Clough and Halley (eds), pp. 110-50. The implicit argument I make here is that the extension of surplus labour that this expectation of a labour freely given has always been the central logic of capitalist re/production. In this, the wage has historically indicated the shifting lines of compensatory exclusion, hierarchy and recognition-rather than being remunerative in any symmetrical sense.

30 Marx was not always alert to the ways surplus labour is constituted by that which exists outside or beyond the wage contract, though it is shaped by it, often in the most intimate of ways. That said, the writings in the Grundrisse and the third volume of Capital complicate the easy distinctions between production, reproduction, circulation and exchange (Capital, vol. III, Penguin, London, 1991; Grundrisse: Foundations of the Critique of Political Economy, Penguin, London, 1973).

31 On the simultaneity of abundance and austerity, Rafferty and Yu note that 'The current crisis can be thought of as paradoxical in the sense that it is a crisis amidst abundance. At its most basic, in Australia, 
GDP per capita has increased by 42 per cent since 1990 alone'. Mike Rafferty and Serena Yu, Shifting Risk: Work and Working Life in Australia. A Report for the Australian Council of Trade Unions, Workplace Research Centre, University of Sydney, September 2010, pp. 4-5. A longer discussion of the connections between this and the political friction over the mining and carbon taxes during the term of the Gillard Government is undoubtedly relevant here.

32 International Monetary Fund, Global Financial Stability Report, April 2005,

$<$ www.imf.org/External/Pubs/FT/GFSR/2005/01/index.htm>.

33 Rafferty and Yu, p. 3.

34 AAP, 'Women Take up Costello's Baby Challenge', Sydney Morning Herald, 2 June 2006.

35 Deborah Brennan, 'Babies, Budgets, and Birthrates: Work/Family Policy in Australia, 1996-2006,'

Social Politics: International Studies in Gender, State and Society, vol. 14, no. 1, 2007, p. 50.

36 Australian Bureau of Statistics, 'Population Projections, Australia, 2006 to 2101',

<www.abs.gov.au/Ausstats/abs@.nsf/mf/3222.0>.

37 Jacques André, 'Le renversement de senglis: histoire et filiation,' CARE, no. 10, 1983, p. 46.

38 This essay was largely written prior to the impending introduction of a carbon tax and the debate over the distribution of any price rises between households and corporations. The Greens made support for such a tax conditional upon the subsidisation of lower- and middle-income households. At the time of writing, however, it remains unclear to what extent this will be the case as the policy is rolled out. On the impact of recycling on increasing domestic labour carried out mostly by women, see Caroline J. Oates and Seonaidh McDonald, 'Recycling and the Domestic Division of Labour', Sociology, vol. 40, no. 3, 2006, pp. 417-33. The debate on recycling is a broader discussion, involving questions about the relative emphasis on household recycling compared to that of changing production methods and energy sources; the energy required to collect, sort, process and deliver reused materials; the health and conditions of low-wage workers in recycling industries; and the consequences of the global trade in hazardous materials in, most notably, the recycling of electrical and electronic equipment. The issue, of course, is not whether there should be measures to reduce environmental damage, but whether the measures undertaken displace the problem and defer solutions, giving the impression of virtuous action while in practice distributing the burden of risk and labour away from large-scale polluters and non-renewable energy users.

39 Andrew Simms, 'Ecological Debt and Climate Change', Open Democracy, 5 December 2005, $<$ www.opendemocracy.net/globalization-climate_change_debate/article_2503.jsp>.

40 On the conjunctures of sexuality, migration policy, welfare and the state more generally in the context of the United States, see Mae M. Ngai, Impossible Subjects: Illegal Aliens and the Making of Modern America, Princeton University Press, Princeton, N.J., 2004; Jacqueline Stevens, Reproducing the State, Princeton University Press, Princeton, N.J.,1999; and Anna Marie Smith, Welfare Reform and Sexual Regulation, Cambridge University Press, New York, 2007. On Australia, see Zoe Anderson, 'One 
"Body/Nation": Pathology and Cultural Citizenship in Australia', Cultural Studies Review, vol. 15, no. 1, 2009, pp. 110-29.

41 Dinesh Wadiwel and Deirdre Tedmanson, The NT Emergency Response: Foucault, Neoptolemus and the Governmentality of New Race/Pleasure Wars, unpublished paper,

<www.unisa.edu.au/hawkeinstitute/publications/foucault-25-years/wadiwel-tedmanson.pdf>.

42 Nicole Watson, 'Of Course it Wouldn't be Done In Dickson! Why Howard's Battlers Disengaged From the Northern Territory Emergency Response', borderlands, vol. 8, no. 1, 2009,

<www.borderlands.net.au/vol8no1_2009/nwatson_dickson.htm>.

43 With the restatement of the provisions of the Racial Discrimination Act, the welfare aspects of the Intervention have more recently been made applicable to welfare recipients irrespective of race. 44 Holly Randell-Moon, 'Social Security with a Christian Twist in John Howard's Australia', in Michael Bailey and Guy Redden (eds), Mediating Faiths: Religion and Socio-Cultural Change in the Twenty-First Century, Ashgate, London, 2010, pp. 203-15. Barbara Baird, 'The Resignation of The Governor-General: Family Drama and National Reproduction', Cultural Studies Review, vol. 15, no. 1, 2009, pp. 65-87. On the latter, see also Joanne Faulkner, The Importance of Being Innocent: Why We Worry about Children, Cambridge University Press, Melbourne, 2011. ( Of course, along with the complaints about Gillard's unmarried status were those which implied her atheism made her politically questionable.) 45 Mutual obligation policies in Australia were, under the Keating Labor Government (1991-96), similarly accompanied by a shift to more draconian border control, notably the mandatory internment of undocumented migrants - though few recall Keating's inaugural speech in 1970 suggesting that, rather than increase the numbers of migrants, women should leave the workforce and return to having children.

46 Michael Rafferty, 'How this Budget put Welfare to Work', The Conversation, 11 May 2011, $<$ theconversation.edu.au/how-this-budget-put-welfare-to-work-846>. To note the parallels with the United States, see Carolyn Cocca, 'From “Welfare Queen: to “Exploited Teen”: Welfare Dependency, Statutory Rape, and Moral Panic', NWSA Journal, vol. 14, no. 2, 2002, pp. 56-79.

47 Misha Schubert, 'Open Season on Julia', Sydney Morning Herald, 10 July 2011.

48 Marlon M. Bailey, Priya Kandaswamy and Udora Richardson, 'Is Gay Marriage Racist?,' in Mattilda Bernstein Sycamore (ed.), That's Revolting: Queer Strategies for Resisting Assimilation, Counterpoint, Berkeley, 2008, pp. 113-21.

49 Angela Mitropoulos, 'Precari-Us?', in Josephine Berry-Slater (ed.), The Precarious Reader, London, Mute, 2005, pp. 12-18.

50 Angela Mitropoulos, 'The Social Softwar', Mute: Web 2.0 - Man's Best Friendster?, vol. 2, no. 4, 2007, $<$ www.metamute.org/en/The-Social-SoftWar>.

51 Akseli Virtanen, 'General Economy: The Entrance of Multitude into Production', Ephemera, vol. 4, no. 3, 2004, 209-27. Paolo Virno, A Grammar of the Multitude, trans. I. Bertoletti et al, Semiotext(e), New York, 2004. 
52 Patricia Ticineto Clough, Greg Goldberg, Rachel Schiff, Aaron Weeks and Craig Willse, 'Notes Towards a Theory of Affect-Itself', Ephemera, vol. 7, no. 1, 2007, 60-77.

53 Kathi Weeks, 'Life Within and Against Work: Affective Labor, Feminist Critique, and Post-Fordist Politics', Ephemera, vol. 7, no. 1, 2007, pp. 233-49.

54 Melinda Cooper 'The Unborn Again: Neo-Imperialism, the Evangelical Right, and the Culture of Life', in Melinda Cooper, Life as Surplus: Biotechnology and Capitalism in the Neoliberal Era, University of Washington Press, Seattle, 2008, p. 171.

55 Angela Mitropoulos, Contract and Contagion: Oikonomia, Intimate Self-Management and the Limits to Speculation (forthcoming), a chapter of which appears as 'Legal, Tender'.

56 I undertake a lengthier treatment of definitions of re/production in Contract and Contagion, noting here that the historical emergence of theories of biological inheritance in the sixteenth century took as their model that of familial property rights and their transmission. In the biological sciences, one could contrast the work of Lynn Margulis to that which conventionally posits family trees (Lynn Margulis and Dorion Sagan, Acquiring Genomes: A Theory of the Origins of Species, Basic Books, New York, 2002). A symbiotic understanding of biological evolution-derived from a consideration of the transfer of genetic information between bacterial cells or viruses and eukaryotic cells-regards the human body, among other apparently discrete bodies, as composed by multiple organisms.

57 While I touched on this in 'Precari-Us?' and 'The Social Softwar', I take it up in an analysis of life insurance, slavery and wage contracts in 'The Time of the Contract', South Atlantic Quarterly (forthcoming 2012).

58 Arlie Russell Hochschild, The Managed Heart: The Commercialization of Human Feeling, University of California Press, Berkeley, 2003, p. 135. 